\title{
ANALISIS PEMBERIAN REWARD DAN PUNISHMENT PADA SIKAP DISIPLIN SD N 01 SOKARAJA TENGAH
}

\author{
Intan Apri Wijaya, Okto Wijayanti, Arifin Muslim \\ Universitas Muhammadiyah Purwokerto, Indonesia \\ intanapriwijayani@gmail.com
}

\begin{abstract}
This research is motivated by the low attitude of student discipline. The author tries to propose the application of reward and punishment as a solution to these problems. This study aims to improve student discipline by implementing reward and punishment. The study was conducted at SD Negeri 01 Sokaraja Tengah with the main focus of the study being to find out the implementation of reward and punishment for disciplinary attitudes. This research activity was carried out in the form of observation, interviews, and data collection with school documentation. The data taken from this study is qualitative data that is data obtained from the results of observations and interviews and documentation. This research was conducted with 3 respondents namely the Principal, teachers and students. Research conducted at SD Negeri 01 Sokaraja Tengah found that in the implementation of rewards and punishments on disciplinary attitudes went well and could provide change by implementing them. Thus it can be concluded, the provision of reward and punishment can improve student discipline.
\end{abstract}

Keywords: Reward and punishment, Discipline

\section{ABSTRAK}

Penelitian ini dilatarbelakangi oleh rendahnya sikap disiplin siswa. Penulis mencoba mengajukan penerapan reward and punishment sebagai solusi atas permasalahan tersebut. Penelitian ini bertujuan untuk meningkatkan sikap disiplin siswa dengan menerapkan reward and punishment. Penelitian dilaksanakan di SD Negeri 01 Sokaraja Tengah dengan fokus utama penelitian adalah mengetahui pelaksanaan dalam pemberian reward dan punishment pada sikap disiplin. Kegiatan penelitian ini dilakukan dalam bentuk observasi, wawancara, dan pengumpulan data dengan dokumentasi sekolah. Data yang diambil dari penelitian ini adalah data kualitatif yaitu data yang diperoleh dari hasil obseravsi dan wawancara serta dokumentasi. Penelitian ini dilakukan dengan 3 responden yaitu Kepala Sekolah, guru dan siswa. Penelitian yang dilakukan di SD Negeri 01 Sokaraja Tengah ditemukan bahwa dalam pelaksanaan pemberian reward dan punishment pada sikap disiplin berjalan dengan baik dan dapat memberikan perubahan dengan dilaksanakan hal tersebut. Dengan demikian dapat disimpulkan, pemberian reward and punishment dapat meningkatkan sikap disiplin siswa.

Kata Kunci: Reward dan punishment, Sikap Disiplin

Submitted November 3, 2019 | Revised December 3, 2019 | Accepted December 5, 2019

\section{Pendahuluan}

Pendidikan merupakan salah satu lembaga yang menjadikan keberlangsungan proses perubahan tingkah laku. Tujuan pendidikan adalah untuk mewujudkan dan menggali potensi yang dimiliki oleh seseorang. tersebut fungsi Pendidikan Nasional adalah untuk mengembangkan potensi dengan membentuk karakter (watak) dengan mencerdaskan kehidupan agar tercapai tujuan tertentu. Membentuk karakter dapat meningkatkan kualitas sumber daya manusia. Pendidikan karakter bertujuan untuk meningkatkan kualitas diri masyarakat pada masa sekarang dan masa yang akan datang. Menurut Yaumi (2014: 72) menjelaskan bahwa pendidikan karakter merupakan suatu gerakan dalam menciptakan sekolah dengan mengembangkan peserta didik yang memiliki etika.

Karakter disiplin merupakan suatu tingkah laku seseorang dalam mematuhi sebuah peraturan. Peraturan yang ada di sekolah maupun di luar sekolah. Menurut Suyadi (2013: 8) menjelaskan 
bahwa disiplin merupakan suatu tindakan yang konsisten dalam mematuhi peraturan yang berlaku. Sikap disiplin harus dimiliki oleh siswa, karena siswa yang memiliki sikap disiplin yang baik akan diterima dan dihargai di sekolah maupun di luar sekolah. Indryani (2012: 102) menjelaskan bahwa disiplin merupakan suatu kepatuhan terhadap peraturan, waktu, serta tata tertib. Permasalahannya siswa masih ada yang jajan ketika jam istirahat sudah selesai.

Disiplin merupakan suatu sikap atau perilaku siswa dalam mematuhi peraturan. Peraturan diberikan untuk membuat siswa menjadi patuh. Imron (2011: 173) mengatakan disiplin adalah suatu keadaan tertib dan teratur yang dimiliki oleh peserta didik di sekolah, tanpa ada pelanggaranpelanggaran yang merugikan baik secara langsung maupun tidak langsung terhadap peserta didik sendiri dan terhadap sekolah secara keseluruhan. Disiplin menurut Mustari (2014: 35) adalah tindakan yang menunjukan perilaku tertib dan patuh pada berbagai ketentuan dan peraturan. Berdasarkan dari beberapa pendapat dapat disimpulkan bahwa disiplin merupakan suatu tindakan atau perilaku tertib dan teratur.

Disiplin merujuk pada instruksi sistematis yang diberikan kepada peserta didik. Untuk mendisiplinkan berarti menginstruksikan orang untuk mengikuti tatanan tertentu melalui aturanaturan tertentu. Biasanya kata "disiplin" berkonotasi negatif. Ini karena untuk melangsungkan tatanan dilakukan melalui hukuman. Dalam arti lain, disiplin berarti suatu ilmu tertentu yang diberikan kepada murid. Di sekolah, disiplin berarti taat pada peraturan sekolah. Seorang murid dikatakan berdisiplin apabila ia mengikuti peraturan yang ada di sekolah. Di sini pihak sekolah harus melaksanakannya secara detail dan tidak memihak.

Siswa dengan dibiasakan untuk berperilaku disiplin akan membentuk sikap disiplin. Sehingga siswa memiliki sikap disiplin untuk kehidupan siswa di sekolah maupun di luar sekolah. Contoh sikap disiplin menurut Sahlan, A \& Prastyo, T, A (2017: 179) antara lain sebagai berikut: 1) Membiasakan hadir tepat waktu, 2) Membiasakan mematuhi peraturan guru, 3) Menyelesaikan tugas pada waktunya, 4) Saling menjaga dengan teman agar semua tugas-tugas kelas terlaksana dengan baik, 5) Mengingatkan teman yang melanggar peraturan dengan kata-kata sopan dan tidak menyinggung, 6) Berpakaian sopan dan rapi, 7) Mematuhi aturan sekolah.

SD Negeri 01 Sokaraja Tengah sudah menerapkan kedisiplinan pada siswa. Sekolah tersebut menggunakan pemberian reward dan punishment kepada siswa agar sikap kedisiplinan siswa meningkat. Program yang dilakukan di sekolah dalam pemberian reward dan punishment dilaksanakan setiap kelas oleh guru masing-masing. Peran guru dalam menerapkan sikap disiplin di sekolah sangat penting. Guru bisa menerapkan sikap disiplin salah satunya dengan strategi pemberian reward dan punishment. Pemberian reward dan punishment merupakan suatu cara untuk memberikan respon siswa agar memiliki sikap disiplin. Penghargaan (reward) adalah sebuah bentuk apresiasi kepada suatu prestasi tertentu yang diberikan, baik oleh dan dari perorangan ataupun suatu lembaga yang biasanya diberikan dalam bentuk material atau ucapan. Dalam organisasi ada istilah insentif, yang merupakan suatu penghargaan dalam bentuk material atau non material yang diberikan oleh pihak pimpinan organisasi perusahaan kepada karyawan agar mereka bekerja dengan menjadikan modal motivasi yang tinggi dan berprestasi dalam mencapai tujuantujuan perusahaan atau organisasi (Suwarto, 2011). Reward merupakan suatu penghargaan atau hadiah yang diberikan oleh guru kepada siswa. Penghargaan bisa diberikan kepada siswa yang paling disiplin melalui pujian atau bentuk apapun. Menurut Purwanto (2011: 184) untuk 
memberikan Reward pedagogis perlu sekali guru mengenal betul murid-muridnya dan tahu menghargai dengan tepat. Reward dan penghargaan yang salah dan tidak tepat dapat membawa akibat yang tidak diinginkan. Guru harus memperhatikan ketika akan memberikan Reward kepada siswa, jangan sampai siswa merasa iri kepada temannya, karena mendapat reward dari guru. Reward yang diberikan kepada seorang anak janganlah hendaknya menimbulkan rasa cemburu atau iri hati bagi anak yang lain yang merasa pekerjaanya juga lebih baik, tetapi tidak mendapat ganjaran. Guru dalam memberikan Reward harus adil dan sama rata ketika ada siswa sama-sama mengerjakan tugas dengan baik. Memberi Reward hendaklah hemat. Terlalu kerap atau terus-menerus memberi ganjaran dan penghargaan akan menjadi hilang arti ganjaran itu sebagai alat pendidikan. Reward dapat diberikan tidak selalu hadiah berupa materi, tetapi memberikan pujian juga akan membuat siswa menjadi termotivasi. Janganlah memberi ganjaran dengan menjanjikan lebih dahulu sebelum anak-anak menunjukan prestasi kerjanya apalagi bagi ganjaran yang diberikan kepada seluruh kelas. Ganjaran yang telah dijanjikan lebih dahulu, hanyalah akan membuat anak-anak berburuburu dalam bekerja dan akan membawa kesukaran-kesukaran bagi beberapa orang anak yang kurang pandai. Ketika akan memberikan Reward sebaiknya guru tidak memberi tahu terlebih dahulu. Pendidik harus hati-hati memberikan ganjaran, jangan samapai ganjaran yang diberikan kepada anak-anak diterimanya sebagai upah dari jerih payah yang telah dilakukannya.

Guru juga memberikan punishment kepada siswa yang melanggar suatu peraturan yang sudah ditetapkan oleh guru berupa hukuman yang mendidik siswa tersebut. Seperti siswa dikenakan sanksi untuk mengerjakan soal-soal tertentu, siswa suruh membuat kliping dan siswa disuruh menyapu ruang kelas dan halaman sekolah. Alasan diberikan hukuman agar siswa lebih menghargai dan tidak menyepelakan sesuatu aturan yang sudah diterapkan. Hukuman yang diberikan tidak terlalu berat ataupun terlalu ringan. Hukuman yang terlalu berat akan membuat anak menjadi trauma dan takut sedangakan hukuman terlalu ringan akan membuat siswa menghiraukan hukuman tersebut. Hal yang dilakukan dalam memberikan hukuman dengan secara bertahap melalui teguran, lalu sanksi. Menurut Yanuar (2012: 54) bahwa ada beberapa alasan yang mendasari mengapa hukuman harus diberikan kepada anak yang telah berbuat salah diantaranya yaitu agar anak tidak mengulang kejadian yang sama, dapat mengambil pelajaran, memiliki konsistensiatas janjinya

Berdasarkan penjelasan di atas bahwa alasan dalam pemberian hukuman agar siswa jera terhadap perbuatan yang tidak baik dan melanggar suatu peraturan. Siswa tidak mengulangi perbuatan yang salah itu lagi. Hukuman diberikan atas perjanjian dan konsekuensi yang sudah disepakati bersama apabila melanggar akan diberikan sankis. Ini semua dilakukan guru sematamata agar anak bertanggung jawab.

Berdasarkan hasil wawancara dengan guru, bahwa tingkat kedisiplinan siswa sudah baik. Hal ini terlihat pada guru menerapkan untuk selalu berpakaian lengkap sesuai dengan peraturan yang ditetapkan, seperti setiap hari senin dan selasa harus memakai dasi dan ikat pinggang. Guru mengecek di sekolah setiap hari senin sudah dipotong kuku dan rambut dari rumah. Meskipun siswa memiliki sikap disiplin cukup baik. Namun masih ada siswa yang kurang memiliki sikap tersebut. Berdasarkan hal tersebut di atas, guru menerapkan program dengan menerapkan reward dan punishment, agar siswa lebih termotivasi dalam bersikap disiplin. 
Penulis tertarik untuk menganalisis pemberian reward dan punishment pada sikap disiplin di SD Negeri 01 Sokaraja Tengah. Reward diberikan ketika siswa berperilaku sesuai dengan peraturan. Bentuk reward yang diberikan guru adalah berupa pujian, tepuk tangan, guru mengacungkan jempol dan guru memberikan hadiah. Punishment diberikan ketika siswa melanggar suatu peraturan yang sudah ditetapkan. Bentuk punishment yang diberikan guru adalah hukuman yang mendidik berupa teguran, membersihkan ruang kelas dan halaman sekolah, pemberian tugas seperti membuat kliping. Perlunya penelitian ini untuk mengetahui peran dalam pemberian reward dan punishment terhadap sikap disiplin yang membuat siswa termotivasi untuk menjadi lebih baik dalam peraturan dan sikap siswa. Penerapan sikap disiplin dengan menerapkan reward dan punishment sudah dilakukan guru. Guru melaksanakan hal tersebut dengan tujuan agar siswa termotivasi untuk memiliki sikap disiplin, tetapi masih ada sebagian siswa yang kurang disiplin meski sudah diterapkan reward dan punishment. Maka peneliti tertarik untuk meneliti analisis pemberian reward dan punishment terhadap sikap disiplin di SD Negeri 01 Sokaraja Tengah.

\section{Metode Penelitian}

Penulis menggunakan metode kualitatif dengan pendekatan deskriptif. Metode penelitian kualitatif adalah metode penelitian yang berlandaskan pada filsafat postpositivisme, digunakan untuk meneliti pada kondisi obyek yang alamiah (sebagai lawan adalah eksperimen) dimana peneliti sebagai instrument kunci, pengambilan sampel sumber data dilakukan secara purposive dan snowball, teknik pengumpulan dengan tringgulasi (gabungan), analisis data bersifat induktif/kualitatif, dan hasil penelitian kualitatif lebih menekankan makna dari pada generalisasi (Sugiyono, 2013: 15). Sukmadinata (2016: 72) pendekatan deskriptif adalah metode penelitian yang paling dasar dalam penelitian kualitatif. Ditujukan untuk mendeskripsikan atau menggambarkan fenomena yang ada baik yang bersifat alamiah maupun bersifat rekayasa. Metode kualitatif lebih menekankan pada pengamatan fenomena dan lebih meneliti ke subtansi makna dari fenomena tersebut. Analisis dan ketajaman penelitian kualitatif sangat terpengaruh pada kekuatan kata dan kalimat yang digunakan. Oleh karena itu, Basri (2014) menyimpulkan bahwa fokus dari penelitian kualitatif adalah pada prosesnya dan pemaknaan hasilnya. Perhatian penelitian kualitatif lebih tertuju pada elemen manusia, objek, dan institusi, serta hubungan atau interaksi di antara elemenelemen tersebut, dalam upaya memahami suatu peristiwa, perilaku, atau fenomena (Mohamed, Majid \& Ahmad, 2010).

Data kualitatif yang diperoleh dalam penelitian ini yaitu data yang berupa kata-kata diperoleh dari observasi, angket, wawancara dan dokumentasi yang berupa buku point siswa dan foto-foto yang telah diubah dalam bentuk kata-kata atau dideskripsikan dengan penjelasan. Sedangkan sumber data dalam penelitian ini adalah guru serta siswa SD Negeri 01 Sokaraja Tengah.

\section{Hasil dan Pembahasan}

1. Pelaksanaan pemberian reward terhadap sikap disiplin

Istilah reward yang diketahui oleh pihak sekolah bahwa reward merupakan suatu penghargaan yang diberikan kepada siswa yang berprestasi dan ketika mendapat nilai paling tinggi 
akan mendapat penghargaan. Reward juga diberikan agar anak merasa senang ketika pekerjaannya bagus. Hal tersebut sejalan dengan teori Purwanto (2011:182), menjelaskan bahwa Reward (ganjaran) adalah sebagai alat untuk mendidik anak-anak supaya anak dapat merasa senang karena perbuatan atau pekerjaannya mendapat penghargaan.

Penghargaan yang diberikan oleh siswa sangat penting agar siswa lebih antusias. Penghargaan juga tidak hanya dalam bentuk materi saja tetapi bisa non materi. Reward merupakan alat pendidikan untuk memotivasi siswa agar lebih semangat dan lebih giat dalam melakukan suatu hal, tetapi dalam pemberian penghargaan guru harus memperhatikan syarat dalam memberikan penghargaan. Hal tersebut sejalan dengan yang disampaikan Purwanto (2011: 184) menjelaskan bahwa untuk memberikan Reward pedagogis perlu sekali guru mengenal betul murid-muridnya dan tahu menghargai dengan tepat. Reward dan penghargaan yang salah dan tidak tepat dapat membawa akibat yang tidak diinginkan. Guru harus memperhatikan ketika akan memberikan Reward kepada siswa, jangan sampai siswa merasa iri kepada temannya, karena mendapat reward dari guru. Demikian dapat disimpulkan bahwa dalam pemberian penghargaan tidak hanya siswa yang berprestasi saja, melainkan siswa yang bersikap disiplin. Penghargaan bisa dalam bentuk materi dan non materi. Pemberian penghargaan juga harus diperhatikan agar tidak salah pengertian bagi siswa.

Pelaksanaan reward di kelas V SD Negeri 01 Sokaraja Tengah bertujuan agar siswa lebih bersikap disiplin. Artinya reward diberikan ketika siswa berperilaku atau bersikap disiplin menaati suatu peraturan perlu diberikan penghargaan atau pujian agar siswa lebih semangat dan teman yang lain ikut bersaing. Pemberian reward terhadap sikap disiplin bertujuan agar siswa lebih bersikap disiplin dengan waktu dan menghargai peraturan yang sudah ditetapkan di sekolah dan di kelas oleh bapak/ibu guru.

Guru memberi penghargaan berupa pujian ketika siswa bersikap disiplin. Siswa yang berangkat tepat waktu dan tidak terlambat akan diberi pujian agar siswa termotivasi dan siswa yang lain ikut berangkat tidak terlambat. Guru memberikan penghargaan yang pertama dilakukan oleh guru pujian, selanjutnya guru memberikan seperti bintang lalu hadiah. Adanya penghargaan siswa lebih disiplin yang tadinya banyak yang terlambat hari demi hari menjadi lebih berkurang.

Kegiatan rutin dapat dikatakan kegiatan pembiasaan yang dilakukan sudah terprogram atau terjadwal dari pihak sekolah. Kegiatan rutin yang dilaksanakan di SD Negeri 01 Sokaraja Tengah dalam pemberian reward terhadap sikap disiplin yaitu guru menerapkan agar berangkat sekolah tidak terlambat dan masuk kelas tepat waktu ketika setelah istirahat. Serta pemberian hadiah ketika pembagian raport, jika siswa mendapatkan peringkat, siswa akan mendapat hadiah dari sekolah.

Kepala Sekolah menjelaskan bahwa sekolah memberikan program setiap menerima raport, siswa yang mendapatkan peringkat akan diberikan hadiah seperti peralatan sekolah. Program ini bertujuan agar siswa lebih semangat dan termotivasi kepada siswa yang mendapat hadiah tersebut. Hal ini sejalan dengan teori macam-macam reward yang diberikan kepada siswa yang disampaikan dengan Purwanto (2011:183) bahwa Reward dapat juga berupa benda-benda yang menyenangkan dan berguna bagi anak-anak.

2. Pelaksanaan pemberian punishment terhadap sikap disiplin

Istilah punishment adalah hukuman atau teguran. Hukuman dan teguran diberikan kepada siswa yang melanggar suatu peraturan yang sudah ditetapkan. Hal ini sejalan dengan teori yang 
disampaikan Imron (2011: 169) bahwa hukuman adalah suatu sanksi yang diterima oleh seseorang sebagai akibat dari pelanggaran atau aturan-aturan yang telah ditetapkan. Guru menerapkan siswa agar disiplin seperti berangkat tidak terlambat, masuk kelas tepat waktu, membuang sampah tidak sembarangan, memakai dasi dan ikat pinggang pada hari senin dan selasa dan memotong kuku dan rambut setiap hari senin guru mengecek. Siswa yang tidak menaati peraturan di atas akan dikenakan sanksi oleh guru. Sanksi yang digunakan yaitu sanksi yang mendidik siswa, seperti memberikan tugas tambahan dan membuat kliping. Tujuan dalam memberikan hukuman agar menambah wawasan siswa tersebut, agar siswa jera dan tidak mengulangi perbuatan atau kesalahan lagi, sehingga siswa disiplin dengan seiring waktu.

Guru kelas V dan kepala sekolah mengatakan bahwa dengan memberikan hukuman yang mendidik siswa yang tadinya sering terlambat menjadi tidak terlambat. Kepala sekolah juga mengatakan bahwa mendidik siswa untuk disiplin agak susah, itu semua pihak guru harus melatih agar siswa lebih bersikap disiplin. Siswa kelas V masih banyak yang terlambat sebelum diberlakunya perjanjian hukuman dalam satu kelas. Setelah guru memberikan perjanjian ketika terlambat akan dikenakan sanksi yang tadinya dari satu kelas hampir sebagian siswa sering terlambat, menjadi beberapa siswa saja yang masih sering terlambat. Gambar mengenai siswa yang terlambat dipaparkan pada gambar 1 sebagai berikut:

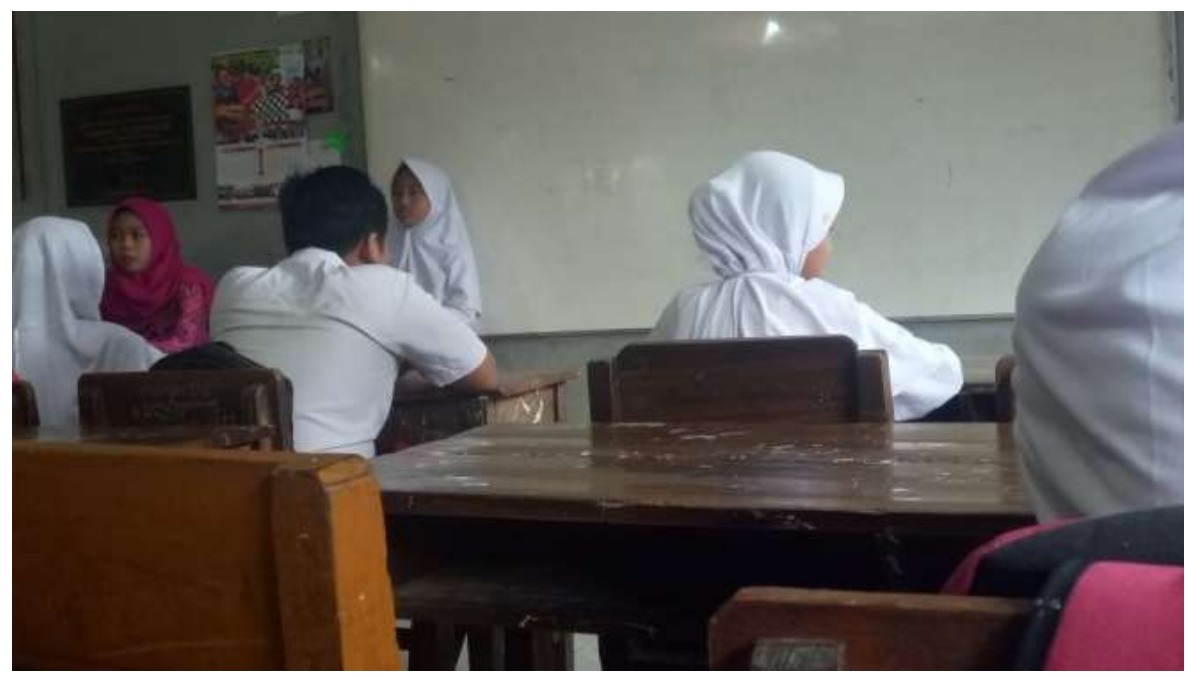

Gambar 1

siswa yang terlambat mendapatkan punishment

Berdasarkan hasil pengamatan dan dokumentasi bahwa siswa kelas $\mathrm{V}$ yang terlambat hanya satu siswa itupun karena benar-benar dari rumah kesiangan. Guru memberi sanksi yang sudah ditetapkan bahwa siswa ketika terlambat akan diberikan sanksi untuk berdoa sendiri di depan kelas, menyanyikan lagu, dan tepuk-tepuk di depan kelas. Adanya kesepakaan tersebut siswa menjadi lebih disiplin yang tadinya banyak yang terlambat menjadi 1 atau 2 siswa saja bahkan tidak ada yang terlambat. Pelaksanaan punishment bisa dibilang berhasil dengan guru menerapkan caracara tertentu agar siswa lebih disiplin. Semua saling mendukung antara pihak sekolah, guru dan orang tua. 
Kegiatan rutin dapat dikatakan kegiatan pembiasaan yang dilakukan sudah terprogram atau terjadwal dari pihak sekolah. Kegiatan rutin yang dilaksanakan di SD Negeri 01 Sokaraja Tengah dalam pemberian punishment terhadap sikap disiplin yaitu guru menerapkan agar berangkat sekolah tidak terlambat dan masuk kelas tepat waktu ketika setelah istirahat, serta pemberian hukuman seperti ketika upacara berlangsung siswa yang tidak lengkap akan diberikan sanksi seperti dibariskan sendiri, selanjutnya diserahkan kepada guru kelas masing-masing untuk diberi sanksi. Hukuman yang diberikan oleh pihak sekolah melalui bertahap dulu yang pertama teguran, ketika teguran siswa tidak mempan, maka guru ataupun pihak sekolah memberikan hukuman yang mendidik. Adanya punishment tersebut yang tadinya banyak siswa yang tidak lengkap, menjadi lengkap.

\section{Kesimpulan}

Pelaksanaan reward dan punishment terhadap sikap disiplin, guru memberikan reward kepada siswa yang berdisiplin, yang pertama guru memberikan pujian kepada siswa yang disiplin, seperti pujian displin berangkat sekolah dan pakaian rapi serta mengerjakan tugas tepat waktu. Adanya reward siswa lebih semangat, ketika temannya mendapatkan reward maka siswa lain juga ingin mendapatkan reward tersebut dan akhirnya siswa tersebut juga lebih semangat untuk mendapatkannya. Sedangkan punishment dilakukan guru ketika siswa melanggar peraturan yang sudah ditetapkan bersama. Guru menggunakan punishment yang pertama teguran jika teguran tidak mempan guru menggunakan hukuman atau sanksi yaitu hukuman yang mendidik seperti membuat kliping dan tugas tambahan. Adanya hukuman yang mendidik siswa lebih patuh dan jera walaupun masih ada beberapa siswa yang kurang patuh.

\section{Daftar Pustaka}

Basri, H. (2014). Using qualitative research in accounting and management studies: not a new agenda. Journal of US-China Public Administration, October 2014, Vol.11, No.10, 831-838. DOI: 10.17265/1548-6591/2014.10.003

Djamarah, S. B.(2008). Psikologi Belajar. Jakarta: Renika Cipta

Imron, A. (2011). Manajemen Peserta Didik Berbasis Sekolah. Jakarta: PT Bumu Aksara

Indrayani. (2012). Pendidikan Karakter. Jakarta: Baduose Media

Mohamed, Z. M., Abdul Majid, A. H., \& Ahmad, N. (2010). Tapping new possibility in accounting research, in qualitative research in accounting, Malaysian case. Penerbit Universiti Kebangsaan Malaysia, Kuala Lumpur, Malaysia.

Mustari, M. (2017). Nilai Karakter: Refleksi untuk Pendidikan. Jakarta: PT. Rajagrafindo Persada

Purwanto, N. (2011). Ilmu Pendidikan Teoritis dan Praktis. Bandung: PT. Remaja Rosdakarya 
Sahlan, A \& Prastyo, T. A. (2017). Desain Pembelajaran Berbasis Pendidikan Karakter. Jogjakarta: ARRUZZ MEDIA

Slameto. (2010). Belajar \& Faktor-Faktor yang Mempengarubi. Jakarta: Rineka Cipta

Sugiyono. (2006). Metode Penelitian Kuantitatif Kualitatif dan RひD. Bandung: Alfabeta.

Sukmadinata, N. S. (2013)..Metode Penelitian Pendidikan. Bandung : PT Remaja Rosdakarya.

Suwarto, M.S. (2011). Perilaku Keorganisasian: Universitas Atma Jaya Yogyakarta

Suyadi. (2013). Strategi Pembelajaran Pendidikan Karakter. Bandung: Rosda

Yanuar. (2012). Jenis-Jenis Hukuman Edukatif untuk Anak SD. Jogjakarta: DIVA Press

Yaumi. (2016). Pendidikan Karakter Landasan Pilar \& Implementasi. Jakarta: Prenadamedia Group 